\title{
Maternal filicides in Toni Morrison's Novels
}

\author{
R.M.Prabha \\ Ph.D. Scholar, Manonmaniam Sundaranar University, Tirunelveli, Tamil Nadu \\ prabharmk@gmail.com
}

\begin{abstract}
Prolicide refers to the act of killing one's own offspring. Filicide is the deliberate act of a parent killing his or her own son or daughter. Parents may be compelled to kill their children for a variety of reasons. Filicide is a byzantine and multi factorial crime. Maternal filicide is child murder by the mother. Reasons for wanting to end the life of a child, particularly a newborn, includes disability, gender, lack of resources to care for the child, or illegitimacy. Toni Morrison's novel is known for maternal filicides. Toni Morrison's mothers kill their own children in nearly five instances. The subject of child murder by mothers seen in Toni Morison's novels is unique. This paper categorizes the murders of children by Morrison's mothers and discusses the characters of the perpetrators who are the factual murderers of body.
\end{abstract}

Keywords: Prolicide, filicide, feticide, offspring, murder.

\section{INTRODUCTION}

The disaster of maternal filicide, or child murder by mothers, has happened throughout history and throughout the world. In developing countries, the preference for male infants may lead to sexselective killings [1]. Many of Morrison's mothers involve in murders of their own children. In her eleven novels, there is evidence of at least five mothers who happen to kill their own offspring. Four of them do it intentionally and one does it inadvertently. Surprisingly, none of the male characters in her fiction has killed their own offspring. Ironically, there is ample evidence in her fiction about the worthiness and goodness of these particular five women who commit prolicide in her novels. Besides this, many other mothers in her novels are more interested in abusing and neglecting their children rather than killing them. They seem to be causing more pain and extreme suffering to the life and minds of such children. The point to be noted is that, abuse of children results in unrelenting pain and suffering, which tolls far eviler effects than the pain that results from filicide.

\section{MURDERS BY MORRISON's MOTHERS}

According to Resnick, Maternal filicide perpetrators have five major motives: Altruism, acute psychosis, unwanted child, accident, and spousal revenge [2]. Altruistic filicide is described as a motive of relieving the child of real or imagined suffering and includes murder associated with suicide. Acutely psychotic filicide involves parents, who kill under the influence of severe mental illness. In unwanted-child filicide, the victim is never or is no longer desired by the parents. These filicides are usually committed due to illegitimacy or uncertain paternity. Accidental filicide is unintentional death due to child abuse, mostly following battered child syndrome. Spousal revenge filicide describes children, who are killed to react against or rebuke the parent's mate.

In an attempt to help in understanding a parent's motivation for killing his or her child, multiple classification systems of filicide have been formulated, based on the type of crime and the gender of the perpetrator. Guileyardo et al. suggested a classification of filicides into 16 subtypes, based on selection of the primary motive or cause [3]. Meyer and Oberman created a classification system identifying the causes of maternal infanticide [4].Scott devised another classification system based on the impulse to kill. The systems serve to better delineate and outline the motives behind these crimes.

Mothers at highest risk of filicide are often socially quarantined, impoverished, destitute, full-time care providers who may have been preys of domestic violence themselves. Unmarried and unemployed women with a lack of social support, limited education, and a history of substance use are also seen to be indulging in filicides. 


\section{Altruistic Filicide}

The parent kills the child because it is perceived to be in the best interest of the child. It could be an act associated with parental suicidal ideation where the parent may believe that the world is too cruel to leave the child behind, after his or her death or it could be an act meant to relieve the suffering and anguish of the child when the child has a disability, either real or imagined, that the parent finds intolerable.

Beloved is Toni Morrison's fifth novel Published in 1987. Toni Morrison constructs the story from fragments, featuring a series of flashbacks to twenty years earlier than the present time of the novel. The maternal filicide in this novel is dramatic and different from others. This filicide has received more attention and criticism than other maternal filicides in her novels. The character Sethe is the fictional representation of real life of Mrs. Garner. Sethe is sold into slavery at a young age, marries, and becomes mother to several children. When faced with the seemingly unbearable thought of living under the oppression of a new and notoriously brutal master, Sethe decides to join the slaves planning to escape. However, the slave owners seize Sethe before she has a chance to escape and steal her breast milk. Sethe's desperate attempt to escape and her horror of a return to slavery push her to the point that she tries to kill her children rather than return them to a life of detention. Sethe is successful only in the infanticide of her daughter, Beloved. Beloved thus explores a strong yet complex biological connection between mothers and daughters. According to Sethe, death is better than to live in slavery. Slavery has demolished her psychological well-being to such an extent that she dreads life amidst slavery. Hence, she kills Beloved in the best interest of the child. Sethe believes that the world is too cruel to return the child to slavery. She kills her daughter in order to relieve the suffering of her child. This is an example for Altruism.

Toni Morrison describes the inspiration for the novel in a conversation with Gloria Naylor. She says she was obsessed by two or three little fragments of stories that she heard from different places. The storyline for the book was inspired by real-life accounts of the experiences of an 1851 slave woman, Margaret Garner. Morrison learned of this slave woman's story through newspaper clippings. She says of Garner, “. . . the Abolitionists made a great deal out of her case because she had escaped from Kentucky ... with her four children. She lived in a little neighborhood just outside of Cincinnati and she had killed her children. She succeeded in killing one; she tried to kill two others. She hit them in the head with a shovel and they were wounded but they didn't die. And there was a smaller one that she had at her breast"'5].Though horrific, Garner's actions represent a mother desperate to protect her children and provide what she felt was the strongest type of motherhood. Later Garner was captured and returned to slavery. Morrison's interpretation of Margaret Garner's story inspires the development of Sethe, the female protagonist in this novel. Morrison was moved by the real-life tragedy of Garner and wanted to develop that into a lasting account of one of the horrors of slavery. Garner, in Morrison's eyes, was a fierce mother who believed in protecting her children with all her might. Hence, in the novel Beloved, the act of Maternal Filicide is altruistic. Here, the helpless mother commits murder in order to save the child from the cruel world full of slavery. The act is perceived to be out of the best interest of the child.

\section{UNWANTEd ChILd FILICIDE}

Unwanted child Filicide is the third type in Resnick's classification. In this type, the parent or the mother kills the child, who is regarded as a hindrance. The victim is never or is no longer desired by the mother. Most often, such a child would be illegitimate and born out of illegal relationship.

In the novel, Beloved Nan tells how she and Sethe's mother "were taken up many times by the crew" during their passage (Beloved37). White men and the crew in the ship sexually abused Nan and Sethe's mother during the middle passage after they were forcibly uprooted from their parent soil, Africa. The next sentences reveal that Sethe's mother had children as a result of being "taken up," endorsing that these words signify rape. Sethe's mother and Nan were repeatedly used for the sexual gratification of the crew. Sethe's mother was so much disgusted by the horrible experience that she abandoned the resultant children. In Nan's words,

She threw them all away but you. The one from the crew she threw away on the island. The others from more whites she also threw away. Without names, she threw them. You she gave the name of the black man. She put her arms around him. The others she did not put her arms around. Never. Never. Telling you .I am telling you, small girl Sethe. (Beloved 37) 
Sethe's mother killed her own children. There was no account given on the number of children she had killed. She suffered at the hands of many men during her long voyage from Africa to the New World. She was taken away from Africa against her will. She was abused against her will. The children who were born out of this forced rape on her were definitely the 'unwanted' ones. She must have been psychologically broken to kill all of them. She killed one on the island and the others she threw them into the water. She saved Sethe alone as she was born to a man she probably agreed to be with. This filicide is an example of 'Unwanted Child Filicide.' Analyzing, in retrospect, had she been saving all of them in order to bring them up would have been impossible for her. The children were not born out of wedlock. They were born because of the inhuman act of the oppressors on their prey. The novel Beloved has two different types of maternal filicides and interestingly these murders are committed by the mother and daughter Sethe. Sethe may have inherited the tendency to alleviate pain by destructing the source of pain or the victim of such pain by a strong willful act.

\section{EUTHANASIA}

Euthanasia is the second type of Filicide in Guileyardo's enhanced classification of Filicide. Euthanasia is the act of intentionally terminating a person's life to relieve suffering. It could be active or passive. It is classified into voluntary euthanasia, non-voluntary euthanasia and involuntary euthanasia.

Euthanasia is seen in Sula, Toni Morrison's second novel published in 1973. Sula is about the story of two black girls, Sula and Nel, from their childhood through their adulthood and Sula's death. Eva is the grandmother of Sula. Toni Morrison has given lot of importance to this particular character Eva. In fact, the main character Sula is designed from the traits of her grandmother Eva. In Sula, Eva is shown to be killing her own son. This maternal prolicide is different from the others. It is an act of Euthanasia from Eva. The character Eva is portrayed strong with determined mind, who believes, and stands by her own decisions. That is evident from the self-harm she brings on to herself in an effort to save her dying children.

Plum is the hope of Eva's family and he returns home after serving as a warrior in World War I. However, Plum is completely fettered, dilapidated, mentally disordered and he is literally turned into a destitute with a sack on his shoulder. Lucille P. Fultz points out, "When Plum returns from the war (which makes him a warrior, like Adonis) mired in heroin addiction, Eva is not able to accept his selfdestructive behaviour, slovenliness, and diminishment to a mere shadow of himself" [5].Initially Eva had planned to bestow everything to Plum. With lots of expectation and joyfulness, Eva looked forward his homecoming from the war field. When his return is delayed a little, Eva is disappointed. However, Plum returns home beyond repair.

Her confidence is shattered. His appearance makes Eva and Hannah to contemplate about Plum and they recognize that something wrong has happened to Plum. Plum does not confess anything about his strange looking and behavior. However, Eva is smart enough to understand her son. She observes the change in Plum's character caused by the war field. It has removed his soul and sent the body to Medallion. On seeing her son's condition, Eva makes up her mind. She prepares her mind to take care of her disturbed son until her last breath. However, she finds it more difficult to take care of a grown up son who is completely diseased by bad habits that he has practiced in the war field. She could not tolerate her son's dilapidated condition. On seeing Plum's struggle to give up his last breath, she decides to ease his pain by killing. Eva kills him fire by pouring kerosene over him and lighting fire. Plum is sleeping, when Eva comes to visit him:

Plum on the rim of a warm light sleep was still chuckling... Now there seemed to be some kind of wet light traveling over his legs and stomach with a deeply attractive smell. It wound itself--this wet light-all about him, splashing and running into his skin. He opened his eyes and saw what he imagined was the great wing of an eagle pouring a wet lightness over him. She rolled a bit of newspaper into a tight stick about six inches long, lit it and threw it onto the bed where the kerosene-soaked Plum lay in snug delight. Quickly, as the _whoosh__ of flames engulfed him, she shut the door and made her slow and painful journey back to the top of the house.... Hannah opened the door. "Plum! Plum! He's burning, Mamma! We can't even open the door! Mamma!" Eva looked into 
Hannah's eyes. "Is? My baby? Burning?" The two women did not speak, for the eyes of each were enough for the other. Then Hannah closed hers and ran toward the voices of neighbors calling for water. (Sula 50)

Fultz expresses his view with regard to Eva's act of euthanasia,

She takes away his life by engulfing him in fire... In what we at first perceive as merciless, inhuman act, we find, although in exaggerated form, a lesson in the ultimate importance of the self-reliance that Sula must come to realize and accept. Scarred, too, like Shadrack, Plum seeks to escape independence through drugs rather than to act responsibly to establish an order and chart a direction for his fragmented life. His infantile behavior is a metaphor for lack of independence. He wanted to return to the womb... As Eva suggests, what Plum sought was not incestuous cohabitation, but escape through rebirth and childhood. $\mathrm{He}$ wanted to become a child again, to return to the parental shelter she once offered, to avoid responsibility for self, as well as to be resorted and made new. Unable to accept either her son's dependence or his inevitable decay, Eva destroys him [6].

Hannah knows from the beginning all about Plum's death. Once she had a long talk with her mother when she felt curious and looked into her mother's eyes. She asked;"But what about Plum? What'd you kill Plum for, Mamma?" (Sula 70). Eva was prompt and gave a matured answer;

"He give me such a time. Such a time. Look like he didn't even want to be born. But he come on out. .... he wanted to crawl back in my wom band well... I ain't got the room no more even if he could do it. There wasn't space for him in my womb. And he was crawl in' back. Being helpless and thinking baby thought sand dreaming baby dreams and messing up his pants again and smiling all the time. I had room enough in my heart, but not in my womb, not no more. I birthed him once. I couldn't do it again. He was growed, a big old thing. Godhavemercy, I couldn't birth him twice. I'd be laying here at night and he be downstairs in that room, but when Iclosed my eyes I'd see him... six feet tall smilin' and crawl in' up the stairs quiet like so I wouldn't hear and opening the door soft so I wouldn't hear and he'd be creep in' to the bed trying to spread my legs trying to get back up in my womb. He was a man, girl, a big old growed-up man. I didn't have that much room. I kept on dreaming it. Dreaming it and I knowed it was true. One night it wouldn't be no dream. It'dbe true and I would have done it, would have let him if I'd've had the room but a big man can't be a baby all wrapped up inside his mamma no more; he suffocate. I done everything I could to make him leave me and go on and live and be a man but he wouldn't and I had to keep him out so I just thought of a way he could die like a man not all scrunched up inside my womb, but like a man." (Sula72)

It is not that Eva could not tolerate the pain, and could not afford to take care of him but simply she decides to ease his pain. Nellie Y. Mckay points out to Eva's perception on death as, "To Eva, death was the ultimate reality. Having given Plum life through tremendous struggles, she could not endure his meandering in the artificial pastiche of death; she took him out of his dope-ridden misery and gave him the real thing" [7].Mckay's statement very well supports Eva. This time she remains choice less. Morrison's mothers do not find choices to relieve their pain rather they are left on a one way track. Similarly, Eva was left with only option to kill. Eva's unaccompanied fight is intended to benefit her children but unfortunately, it ends in tragedy due to the poor social order.

\section{UnWANTEd Pregnancy OR NeOnaticide}

Feticide is an act that causes the death of a fetus. Women who commit neonaticide are usually younger, are often unmarried, often deny and/or hide their pregnancies, have a lack of prenatal care, and have no plans for the care of the child [8].Almost all neonaticides are committed by mothers. In the novel Paradise, there is illustration of a mother who tries to kills her child, before even giving 
birth. She attempts to kill him by bringing him out prematurely and succeeds in her venture. The character Arnette Fleetwood of Paradise is portrayed as a young girl, who bears the child of her boyfriend K.D. Morgan. Later, they break up on some issues. The child she carries becomes unwanted and she decides to take away the life of the child. Arnette was just fifteen years old when she is pregnant. She is not married. Toni Morrison's novels have many of such minor girls becoming pregnant with premature relationships with males. In the same novel Paradise, another high school girl, Pallas also lives with a person before marriage and becomes pregnant. She was only sixteen years old, when she is pregnant and decides to save the child. School girls' becoming pregnant is nothing, but a disastrous social evil. However, Arnette did not want to continue with her pregnancy. She goes to the convent for help and she was "sharp in her refusal to have the midwife attend her, waited quietly sullen for a week or so" (258). Arnette did not know how to abort the child. People in the convent urged her to save the child. However, Arnette instigated her own methods of aborting the child:

...the young mother had been hitting her stomach relentlessly. Had Consolata's eyesight been better and had the girl's skin not been black as an ocean lover's night, she would have seen the bruises at once. As it was, she saw swellings and wide areas where the skin showed purple underneath, rather than silver. But the real damage was the mop handle inserted with a rapist's skill — mercilessly, repeatedly—between her legs. With the gusto and intention of a rabid male, she had tried to bash the life out of her life. And, in a way, was triumphantly successful. The five-or six-month baby revolted. Feisty, outraged, rigid with fright, it tried to escape the battering and battered ship that carried it. The blows to its delicate skull, the trouncing its hind parts took. The shudders in its spine. Otherwise there was no hope. Had it not tried to rescue itself, it would break into pieces or drown in its mother's food. So he was born, in a manner of speaking, too soon and fatigued by the flight. But breathing. Sort of. (Paradise 259)

The convent women all gathered to try to rescue the new born. However, all their efforts went in vain. Grace was there trying to save the child. Then Mavis took over. Grace went to bed, "Together Consolata and Mavis cleaned his eyes, stuck their fingers in his throat, clearing it for air, and tried to feed him. It worked for a few days, then he surrendered himself to the company of Merle and Pearl"(Paradise 260). Arnette never bothered to touch or see her son. "By that time [Death of the child] the mother was gone, having never touched, glanced at, inquired after or named him"(Paradise 260). This abortion in Toni Morrison's novel is the ninth type, "Unwanted pregnancy or neonaticide," in Guileyardo's Enhanced Classification System. It is an attempt to kill the fetus, before it was born. There seems to be only a slight difference between unwanted child and unwanted pregnancy. Arnette, in Paradise is an immature girl to become a mother so soon in her life. Her boyfriend disposes her and leaves her. She is alone without any support and hence she takes the decision to kill the child. However, later it is learnt that Arnette marries the same person, K. D. Morgan due to social issues. In the first day of her marriage, she becomes temporarily psychotic and runs to the convent to claim her dead son. All this while she had been contemplating on her act of attempting to kill her own son. Toni Morrison is disturbed by this particular social evil, 'Teen Pregnancy.' A school-going girl becoming pregnant and eventually wanting to abort the fetus are the results of sheer ignorance and lack of moral values that will hinder the empowerment of women. Paternity is the foremost reason that teen girls drop out of school. More than half of teen mothers by no means graduate from high school. Teen pregnancy affects the long-term well-being of the affected families and thereby the community. Toni Morrison is telling the readers about the magnitude of the issue and she wants them to find ways to curb it.

\section{Unintentional Prolicide}

In Toni Morrison's Paradise, there is Mavis, a mother who happens to kill two of her children accidentally. The act was purely unintentional. This type does not fit into any of the conventional classification systems, as the systems include purely intentional murders or abuses only. Mavis Albright is a woman who lets her twins die of suffocation in a car while she is inside a grocery store buying wieners. In Paradise, this is just an accident and it is not a planned murder. Mavis feels guilt 


\section{R.M.Prabha}

for allowing the deaths of her children though, she denies that she was away for more than a few minutes and that guilt drives her to believe that her husband and remaining children are planning to kill her.

Toni Morrison starts the particular chapter by pointing out the envy of the neighbors on the family of Mavis. She says, "The neighbors seemed pleased when the babies smothered. Probably because the mint green Cadillac in which they died had annoyed them for some time" (Paradise 28). Later, the interviewer from media comes to ask Mavis, "So you left the newborns in the car and went in to buy some chuck steak — " and Mavis replies, "No, m'am.Weenies."“Right. Wieners."

Everyone was astonished as to how in a short time the babies can be smothered in a closed car. One thing to remember is that both the children were too young and were just infants. The environment may have been too hot to build up de-oxygenated air within a short time inside fully closed car. The interviewer said, "But what I want to ask is, why did it take so long? To buy one item... Your babies suffocated, Mrs. Albright. In a hot car with the windows closed. No air. It's hard to see that happening in five minutes." Mavis promptly replies, "It didn't. Take long. I couldn't of been in there more than five minutes, tops" (Paradise 30).Toni Morrison has incorporated such a dreadful incident where two infants (twins) die in a closed car due to heat stroke in her novel Paradise. Probably, the author would have been moved or touched at some point, when she learnt about the actual statistics, which says, nearly 38 children die in the U.S in a year as a result of heat stroke in a locked up car[9]. Research says that younger children succumb more readily than older children do. This may be a simple public awareness that Toni Morrison wanted to bring into the society about safety and protection of young children.

\section{DisCUSSION}

The maternal filicides in Morrison's novel are explored. However, analyzing the five mothers of Morrison, who murdered their own children, reveals an interesting fact that all these mothers are first sane and most of them are good-hearted women. Eva, Sethe, Sethe's mother, Mavis all of them are rational and good at their heart. Arnette Fleetwood is too young to carry a child. She is too young to become pregnant. Teen Pregnancy is a social evil that Morrison wants to address. It is the circumstance, which leads these five women to commit such heinous crimes of killing their own children. Moreover, the lost life seems to costs them and the community, much less. It is Sethe and Mavis who suffered for a long time after they have lost / killed their own children. Mavis repents all her life and Sethe is haunted for a long time. However, the mothers, Arnette and Sethe's mother never seem to have been disturbed by their act of killing their un-wanted progeny. Eva practices euthanasia and was in fact happy after what she did to her only son. None of these mothers had any form of psychiatric illness to complicate the issue.

Research says that multiple stressors such as economic and social stress, abuse history, partner relationship problems, primary caregiver status, and difficulty caring for the child are the frequent causes that make a mother kill her children. The similarities between men and women who commit filicide include

1) The presence of significant life stressors

2) Social isolation and lack of social support

3) A history of abuse in childhood

Sethe in slavery has tremendous physical and mental stress. She is abused by the nephews of the schoolteacher. She is raped when she was pregnant. Her breast milk is stolen. She is stressed to the point that there is no further redemption. Such is the case for many mothers in Slavery. Even Sethe's mother was tormented by sexual abuse in the ship. Arnette suffers from social isolation. In Eva's and Mavis' case the situation is entirely different. Eva had to practice euthanasia to save the dying 'self' of her only son. Eva eases the suffering of her son by killing him. Mavis actually does not intend to kill her children. She was only indirectly responsible for their death. She was careless and thoughtless to leave the children in a closed car in hot weather. She is out for a while when her twin children succumbs to death in the hot car. Though she does not do it intentionally, she is careless and ignorant to save her children. Knowledge about hot cars is imperative for all parents to prevent such disasters. This is just a message that Toni Morrison wants to pass on to the community to prevent such deaths. Morrison may be worried that the community may not know the implications of closing a car tight in 
hot sun. Hence, in the five instances of Prolicides, Morrison addresses one social evil, the 'Teen Pregnancy,' and emphasizes on the social awareness to prevent child deaths in hot cars. In other forms of Prolicide, Morrison portrays the way of resistance to oppression of black women in slavery.

\section{Conclusion}

Maternal filicide is a running theme in Toni Morrison's fiction. Women suppressed from all directions are prone to commit such crimes. It is a form of resistance to oppression, that suppressed women practiced. By killing their own children, Slave mothers resisted the oppression on them. Both Sethe and her mother were oppressed because of Slavery. They were abused sexually and physically. They were tormented so badly that some have lost their sense of 'self' to indulge in such crimes. It is a result of lack of social support for some mothers to commit such crimes. Lack of support and huge stress in life during her teenage is the reason for Arnette to kill her own son. Eva just practiced a form of euthanasia. Her situation justified her actions. Mavis was only indirectly responsible for the death of her two kids. It was an accident in her case. Therefore, maternal child murders are a unique theme that is repetitive in Toni Morrison's fiction. Toni Morrison writes about oppressed women, especially black women. As she writes about the life and suffering of women, she incorporates these dreadful incidents in their stories as well. In a way, Morrison points out at the huge capability of woman and teaches the world what a woman can do, can have no known boundaries. Morrison's women have no limits. It is not the inadequacy but the rigidity and inner strength is what she wants the readers to appreciate. Hence, in Morrison's novel various mothers kill their own children at different situations, not to bring defame to 'Morrison's Mothers,' but to express just their emotions.

\section{WORKS CITED}

\section{Primary Sources}

Morrison, Toni. Beloved. London: Vintage Books, 1987. Print.

— Paradise. New York: Plume, 1999. Print.

— Sula. London: Vintage Books, 1973. Print.

\section{Secondary Sources}

[1] Hesketh T. Xing ZW. Abnormal sex ratios in human populations: causes and consequences. ProcNatlAcadSci USA. 2006;103:13271-13275.

[2] Resnick P J: Child Murder by Parents: A Psychiatric Review of Filicide. American Journal of Psychiatry 126:325-34, 1969.

[3] Guileyardo J M, Prahlow J A, Barnard J J: Familial Filicide and Filicide Classification. American Journal of Forensic Medicine and Pathology, 20:286-92, 1999.

[4] Meyer C, Oberman M. Mothers Who Kill Their Children: Inside the Minds of Moms from Susan Smith to the "Prom Mom." New York, NY: New York University Press; 2001. Print.

[5] Naylor Gloria. A Conversation: Gloria Naylor and Toni Morrison. From the Southern Review, 21(1985): 567 -93.

[6] Fultz, Lucille P. Toni Morrison: Playing with Difference. University of Illinois Press, Urbana and Chicago, 2003.

[7] McKay, Nellie Y. Critical Essays on Toni Morrison. G. K. Hall \& Co. Boston, Massachusetts, 1998.

[8] Resnick PJ: Murder of the newborn: a psychiatric review of neonaticide. American Journal of Psychiatry. 126:1414-20, 1970

[9] Ragusea Adam. "Why Hot Cars Are So Deadly?" in Here and Now (July 21/ 2014).Web. 29 April 2016. 


\section{AUTHOR'S BIOGRAPHY}

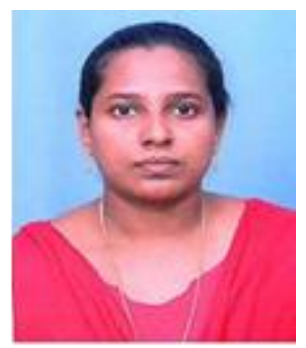

R.M.Prabha, is a research scholar, currently pursuing her Ph.D. course at the Manonmaniam Sundaranar University in Tirunelveli. Her main area of interest is fro-American literature. She has extensively done research on the Afro-American author Toni Morrison and her novels. She completed her undergraduate [B.A English] degree course at the Govindammal Aditanar College for Women in Tiruchen during2006. She did her Master's degree in English [M.A] and subsequently M. Phil. degree in Sarah Tucker College for Women in Tirunelveli. After her graduation she has served the college in which she did her undergraduate degree, as a faculty, Assistant Professor in English forn early four years. Her project for her M. Phil degree was on the novel Jazz by Toni Morrison. Her current research work also involves Toni Morrison's select novels. 